Island Studies Journal, Vol. 4, No. 1, 2009, pp. 3-24

\title{
Ecotourism in Dominica: Studying the Potential for Economic Development, Environmental Protection and Cultural Conservation
}

Vanessa Slinger-Friedman

Department of Geography and Anthropology

Kennesaw State University

Georgia, USA.

vslinger@kennesaw.edu

\begin{abstract}
Over the last 20 years, the government of the small Caribbean island nation of Dominica has pursued the development of ecotourism on the island. The hope is that this industry will promote dispersed economic development while providing environmental protection and cultural conservation. However, not enough has been done to determine whether or not the industry is achieving the desired results. To this end, this study explores the growth of the tourism industry on Dominica and shows that, while not perfect, ecotourism is providing some definite benefits to the island in this regard.
\end{abstract}

Keywords: Caribs cultural conservation, Dominica, economic development, ecotourism, environmental protection, islands

(C) 2009 - Institute of Island Studies, University of Prince Edward Island, Canada

\section{Introduction}

Since the 1990s, Dominica has experienced a significant decline in the export of bananas, its principal crop, due to weather conditions and loss of preferential trade access in European markets. In response, the Dominican government has pursued the development of the ecotourism industry on the island. Ecotourism is considered to have strong potential for economic growth and diversification because of the island's abundance of mountains, streams, forests, and spectacular flora and fauna, as well as its unique indigenous culture.

The hope of many in academia, national governments, and the tourism industry is that ecotourism will be the antithesis to conventional mass tourism. Historically, sun, sea, and sand tourism in the Caribbean has been linked to large scale, foreign-owned and run facilities, the destruction of the environment, rising imports, the repatriation of profits, polarized development, and the loss of cultural identity (Archer, 1998; Brohman, 1996; Blommestein, 1995; Britton, 1982; Caribbean Tourism Organization [CTO], 1999; Klak \& Flynn, 2008). On the other hand, ecotourism, which involves visitors enjoying the natural environment and culture of a location, has expanded in meaning to incorporate tourist education, environmental conservation, benefits to the local population, and the sustainability of local cultures. However, a review of studies on ecotourism in other wellknown ecotourism locations - such as the Galápagos Islands, Costa Rica, Belize and Kenya - have shown that, while some small, locally-inspired projects are promising, large, foreign-owned establishments have generally dominated the tourism industry and are 
favoured by local governmental policies (Honey, 1999, 2008; Place, 1998; Weaver, 1998; Woods et al., 1998).

The study of ecotourism in Dominica is important for several reasons. First of all, the island, with strong government backing in the form of policies and planning, is trying to develop a deliberate and comprehensive ecotourism industry. Second, Dominica has a land area of 290 square miles $\left(750 \mathrm{~km}^{2}\right)$ and is a small enough island for the entire country to be studied and for any policy impacts to be more readily observable. Third, a literature review shows that research on ecotourism in small island developing nations remains lacking. Finally, and on the more practical side, ecotourism is growing in importance to many Caribbean islands as they lose preferential access to markets for their agricultural produce and recognize the negative effects of traditional tourism.

\section{Tourism Development in Dominica}

With bananas as the principal crop, agriculture is the economic mainstay of Dominica (Bonnerjea \& Weir, 1996). Bananas were introduced from the Canary Islands in 1516, and since the mid-1950s have been so important to the country's economy that they were nicknamed 'Green Gold' (Latin American Bureau, 1987). However, the agricultural sector of Dominica has been vulnerable to hurricanes, fluctuations in world market prices, and especially to the decline in preferential trade access to European markets. Due to these factors, Dominica's banana exports decreased from US\$38 million in 1988 to less than US\$5 million in 2003 (Euromonitor International, 2007). Concurrently, the number of banana farmers fell from 4,366 in 1995 to 1,400 in 2003 (Encyclopedia of the Nations, 2008; Progressive Policy Institute, 2004). As a result, the Dominican government has increasingly focused on economic diversification, and much of this effort has been centered on the development of ecotourism.

Worldwide, tourism has long been used as a strategy for promoting economic development in developing countries by providing foreign capital earnings, employment, and linkages to other sectors of their economies (Asiedu, 1997; Brohman, 1996). Since the 1970s, tourism based on the availability of the sun, sea and white sand beaches has been a key element in the economic development plans for many Caribbean islands. Tourism in the insular Caribbean has increased its market share and out-performed the industry worldwide (Duval, 2004; McElroy, 2004). However, the projected economic benefits of tourism in the Caribbean have been mixed, and even proven illusory. Apart from, or instead of, the desired positive impacts, traditional tourism has often been associated with foreign ownership, profit repatriation, accentuation of regional disparities, and environmental and cultural destruction (Klak, 1998). 


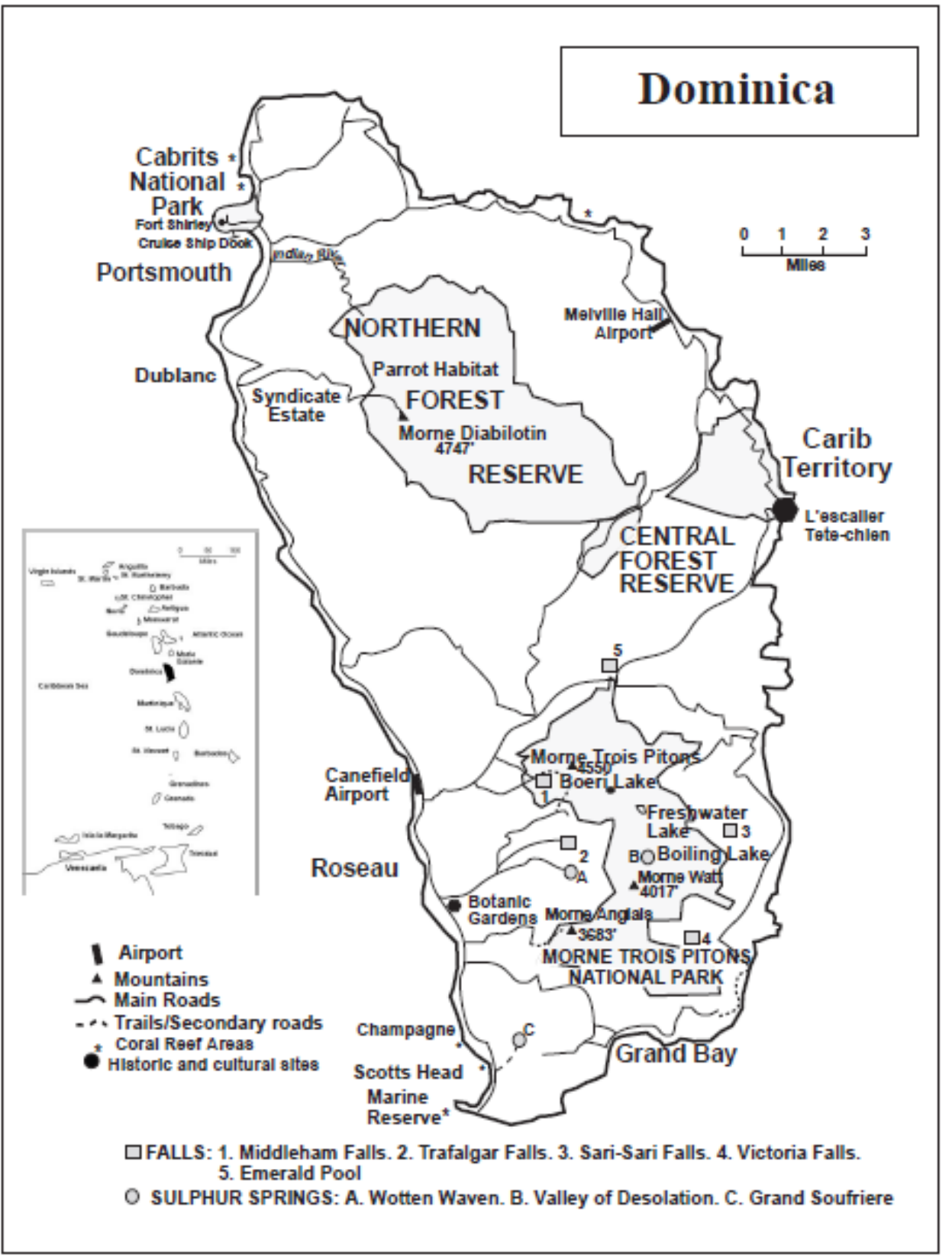

Figure 1: Map of Dominica 


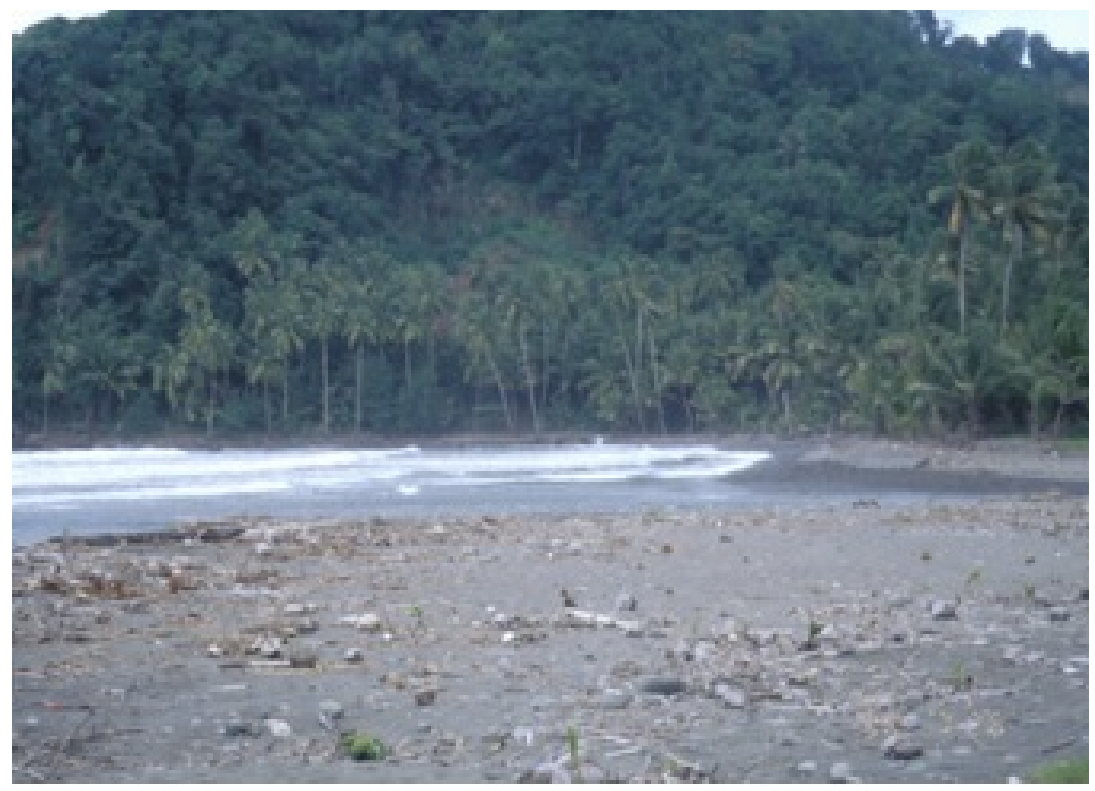

Figure 2: Steep coastlines and volcanic black sand beaches of Castle Bruce on Dominica's North-east coast. (Photo taken by the author)

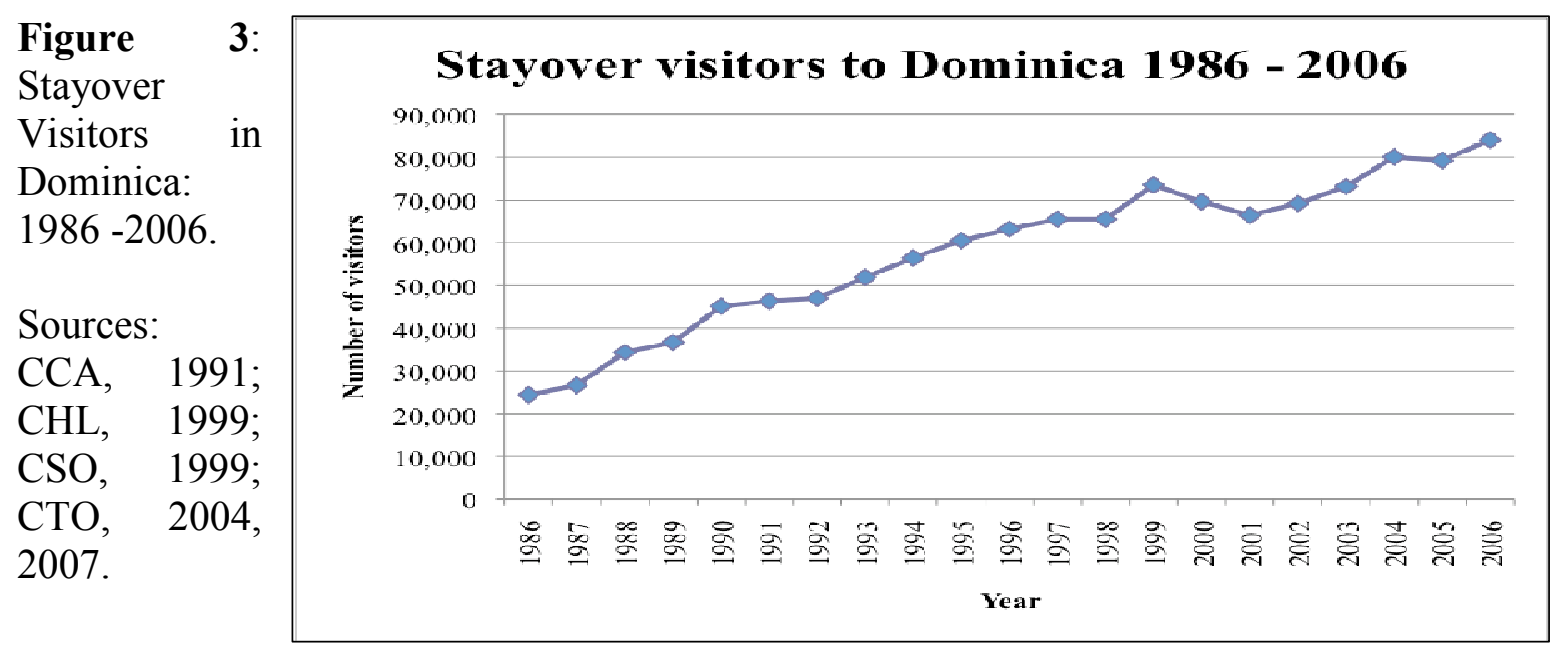

In this most tourism intensive region of the world, Dominica captures less than $1 \%$ of tourists to the Caribbean (WTO, 2009). However, Dominica represents an alternative form of tourism experience demanded by more and more visitors from key international markets. The demand for ecotourism has grown simultaneously with the recognition of the environmental concerns associated with the conventional mass tourism most common in the insular Caribbean.

Whereas many other Caribbean islands turned to the traditional 'sun, sea, and sand' type of tourism, Dominica's mountainous terrain, rocky shores, and black sand beaches deterred its development in this direction (Figures 1 and 2). Tourists to Dominica were scarce until the 1980s, when the government decided to capitalize on the island's unique physical and cultural assets by promoting Dominica as an ecotourism destination (Hulme, 2007). This 
type of tourism seemed ideal due to Dominica's abundant tropical rainforests, hot sulphur springs, waterfalls, whale watching opportunities, the Boiling Lake (the second largest boiling fumarole in the world), and the presence of the Caribs, the last remaining group of indigenous people in the Caribbean. Other biological assets identified as tourist attractions are the thousands of species of flowering plants, including 74 species of orchid and 200 ferns and over 5,000 species of vascular plants. There is also a large bat and bird population, including the Sisserou (Imperial) and Jaco (Red-necked) parrots, both of which are endangered and endemic to Dominica (Halcrow, 2003; Honychurch, 1991). The seemingly endless supply of rainwater also feeds the numerous lakes and rivers on the island, some of which are navigable and full of interesting biophysical features. The best example of this can be found on the Indian River, where boat trips take tourists through winding, mangrove- fringed waters.

Dominica might have initially started out as a "circumstantial" alternative tourism destination (Weaver, 1991). Its lack of white sand beaches and insufficient flat land for an international airport limited its involvement in traditional tourism. However, Weaver (1991) points out a shift in perception by the Dominican government with the realization that the island's natural resource base could be an asset to tourism development rather than a liability. Over the last three decades, the Dominican Government's pursuit of a deliberate alternative tourism strategy is reflected in numerous tourism plans and policies that have been commissioned by or on behalf of the Dominican government in order to formulate a national tourism policy (Ministry of Tourism and National Development Corporation (NDC), 2005; Weaver, 1991), and Dominica's share of tourist arrivals to the Caribbean has been growing steadily. For the period of 1989 to 1993, Dominica had the highest annual increase in visitor expenditure among the Caribbean islands (Hypolite et al., 2002). The Dominican tourism sector contributed an estimated US\$43 million in direct visitor expenditures in 2003 (Ministry of Tourism and NDC, 2005). Since 1986 stayover tourist arrivals to the island have grown annually by almost $7 \%$ (Figure 3 ), and they generate as much as $88 \%$ of tourism revenues for the island when compared to cruise ship visitors (Ministry of Tourism and NDC, 2005).

Despite the Dominican government's ecotourism policy focus, the number of cruise ship visitors to Dominica has also grown significantly, and now far exceeds the number of stayover visitors (Figure 4). Most researchers consider cruise ship tourism to run contrary to the goals of ecotourism because it is often associated with limited local economic impact and potential environmental degradation caused by a large quantity of tourists visiting environmentally sensitive areas (Honey, 2008). The Government of Dominica has dealt with the apparent contradiction between promoting stayover tourism and courting cruise tourism by developing and promoting multiple terrestrial visitation sites for cruise ship tourists. Their goal is to keep the pressure low at any one particular site while obtaining dispersed regional development on the island. To this end, twenty heritage and natural attractions were added in the process (Johnson, 2006). Additionally, the government hopes that cruise ship passengers who experience Dominica for only a few hours will potentially return to the island as stayover tourists ${ }^{1}$.

\footnotetext{
${ }^{1}$ To date, there has been, to the author's knowledge, no research on Dominica to confirm such a direct correlation. However, research undertaken in the Cayman Islands by Shamsub et al. (2006) indicates that an
} 


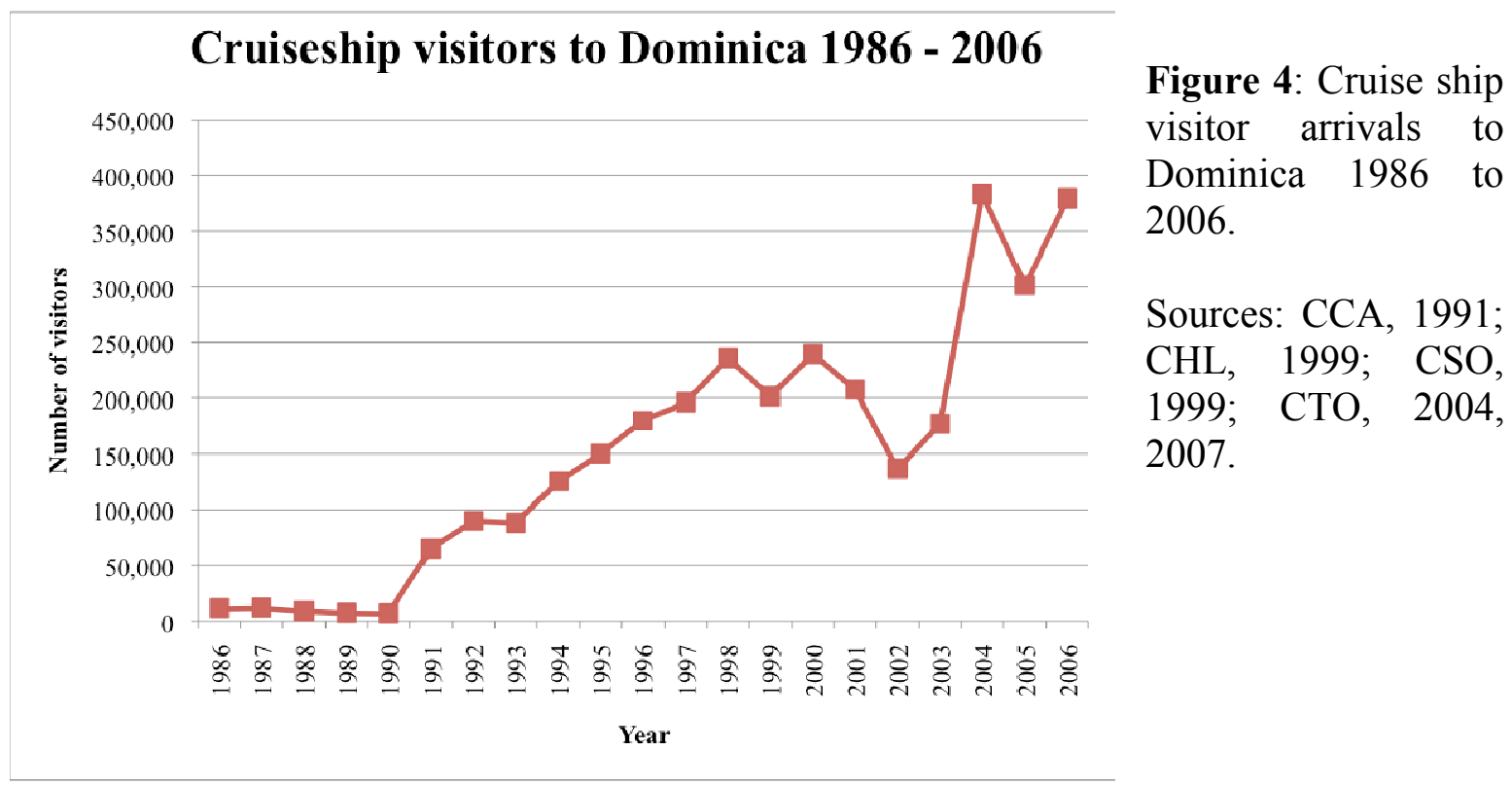

\section{The Study of Ecotourism on Dominica}

Fieldwork and secondary data collection was carried out between 1999 and 2008 to see if ecotourism in Dominica is having the desired results of local involvement, dispersed regional development, linkages with other sectors of the economy, and environmental and cultural preservation.

In 2000 and 2004, fieldwork was carried out on Dominica by the author to complete survey questionnaires with individuals from accommodation facilities, restaurants, tour companies, tour guides, and craft sellers from around Dominica ${ }^{2}$. In all, 75 accommodation facilities, 21 restaurants, 43 craft sellers, 5 dive shops, 18 tour companies and 20 guides, 26 taxi operators, and 56 farmers, fishermen, and hucksters (local term for middlemen) completed surveys and answered questions relating to tourism in Dominica. The hotels and dive shops surveyed represented roughly $68 \%$ and $70 \%$, respectively, of these types of facilities on the island. The total size of the other groups surveyed is unknown because there typically is no formal organization to which they belong. Even where there are formal groups, many people chose not to belong to these organizations, making it difficult to determine exact participation in the tourism industry. However, based on the small size of the island and the time spent doing detailed studies of specific individuals and communities, I feel that the data collected portrays an accurate picture of tourism on Dominica. Interviews with farmers and hucksters who are presently involved in servicing hotels and restaurants with food, as well as hotel and restaurant owners themselves,

increase in the number of cruise ship passengers increases the number of stayover visitors; and that cruise ship tourism complements stayover tourism. Additionally, some researchers argue that there is evidence of a convergence between mass tourism and ecotourism, with mass tourists becoming more aware of environmental concerns (Ayala, 1996; Johnson, 2006).

${ }^{2}$ For a copy of survey instrument, see the annex on the Island Studies Journal website. 
revealed participation in the industry and inter-sectoral linkages between ecotourism and other parts of the Dominican economy, including agriculture, fishing, and forestry.

Secondary data was also gathered from 2000 to 2008 from official government documents, other non-government organizations, and a literature review of current and relevant academic studies. This study looked at three main research areas: (1) creation of employment, economic opportunities, and infrastructural development; (2) linkages formed between tourism and other sectors of the Dominican economy; and (3) conservation of the environment and local indigenous culture.

\section{Research Results}

\section{Economic Impacts}

The first research area was the impact of ecotourism on employment creation, economic opportunities, and infrastructural development. Direct employment in the Dominican tourism industry is estimated to have grown from two hundred people in 1974 to roughly $2,500^{3}$ or approximately $10.3 \%$ to the total work force in 2005 (U.S. Department of State, 2009; CHL, 2006). Tourism's contribution to Dominica's gross domestic product ranges from $10 \%$ to $25 \%$; the higher estimates take into account a multiplier effect that factors in indirect employment generated in such industries as agriculture and fishing. Tourism also generated over $30 \%$ of the country's foreign exchange: three times the earnings from bananas in 2001 (Halcrow Group Ltd., 2003).

A 1993 Caribbean Tourism Organization survey indicated that the majority of tourists coming to Dominica do so to enjoy its natural beauty and tranquility (CTO, 1993). This was evident by the importance that the respondents attached to sightseeing, peace and quiet, and the interest shown in natural history, including the Carib Territory. In addition, a 1995/96 survey of stayover tourists carried out by a consultant for the Dominican government showed that almost ninety-three percent of visitors had already visited a nature site (Westbrook et al., 1997).

A stayover visitor survey carried out in 1995/1996 (Westbrook et al.,1997), found that expenditures per person were highest for visitors who were coming to Dominica primarily with an interest in nature, with an average of US $\$ 883.50$ when compared to an average of US\$576.90 for those on a general vacation. Another factor adding to the potential increased local value of Dominica tourism is the fact that pre-paid packages are seldom used by visitors coming to Dominica. Four out of five visitors make their own travel arrangements (CTO, 1993).

This study found that a diverse number of employment opportunities are being created in the ecotourism industry in Dominica, including positions in the accommodation sector, construction, food preparation, local craft production and sales, agriculture, fishing, park

\footnotetext{
${ }^{3}$ Dominica's Minister of Tourism announced in January 2009 that the tourism industry is responsible for approximately 5,000 jobs, both directly and indirectly (Caribbean Net News, 2009).
} 
maintenance, diving, and touring in both the rural and urban areas of Dominica (Figure 5). These opportunities ranged from manual work to managerial and ownership positions. Based on the research, there is a predominance of Dominicans at every level of employment in the tourism industry. Dominicans filled $96 \%$ of all positions in the tourism industry, including $93 \%$ of professional and managerial positions in the same industry (Table 1). In addition, $92 \%$ of all survey respondents $(\mathrm{N}=264)$ said that they did not have to resettle in order to be involved in the ecotourism industry: this suggests that ecotourism is creating employment opportunities that are regionally diverse. Overall, information gleaned from interviews indicated that respondents did not have to travel a significant distance to their tourism job. Economic opportunities through tourism are also being created in the accommodation sector, diving facilities, and craft shops.

Table 1: Local versus Foreign Employment in the Dominican Tourism Industry $(\mathrm{N}=119)$

\begin{tabular}{|l|c|}
\hline \multicolumn{1}{|c|}{ Data } & Percent \\
\hline Positions in the tourism industry filled by Dominicans & 96 \\
\hline $\begin{array}{l}\text { Professional/managerial positions in tourism industry filled by } \\
\text { Dominicans }\end{array}$ & 93 \\
\hline Would prefer to hire locals as employees in their business & 100 \\
\hline
\end{tabular}

Source: Surveys with Dominican accommodation facilities, restaurants, dive shops, tour companies

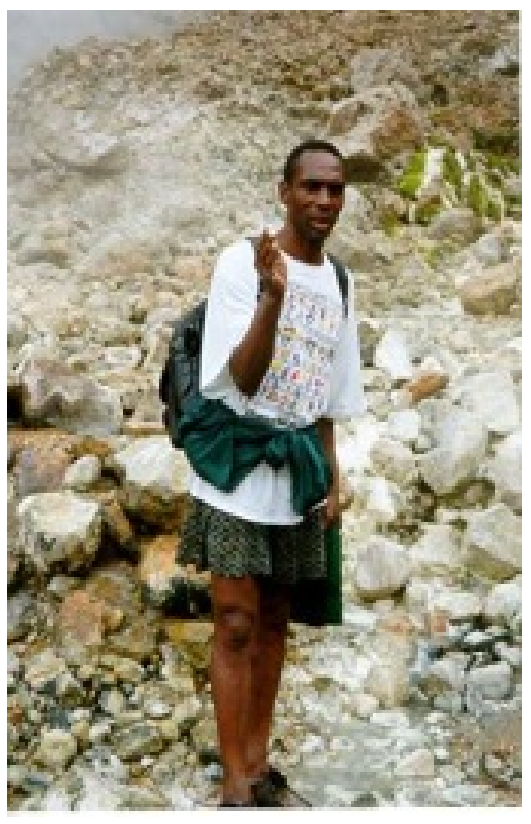

Surveys show that increases in income since being involved in the tourism industry vary greatly and not all respondents were willing to provide detailed financial information. However, over three quarters of the respondents said that they experienced an increase in their monthly or yearly income since being involved in the tourism industry. While hotel owners were not willing to give specific details, some tour guides reported annual incomes of about US\$3,350, some dive instructors reported annual earnings of roughly US\$4,500, and someone in the craft shop business reported annual earnings of close to US\$6,700. All of these earnings exceeded the per capita GDP of Dominica.

Figure 5: Local Tour Guide at the Boiling Lake in the Valley of Desolation. (Photo: taken by author) 
Moreover, almost half of the hotel respondents mentioned adopting behavior in response to changes in tourism demand, including slightly reducing staff numbers or closing the business to take a vacation. A large number of total respondents $(86 \%)$ also stated that they had alternative sources of income other than tourism revenue. These alternative sources of income, often supported by occupational multiplicity; they include small gardens, remittances from abroad, access to pensions, and public sector employment.

While the strip of overnight accommodation in and around the urban area of Dominica's West points to a slightly higher concentration of units in this area, the overall pattern of units in Dominica is dispersed throughout the country (Table 2). Additionally, the concentration of rooms in the West urban area has declined from $49 \%$ in 2000 to $44 \%$ in 2008. Analysis of craft shops and vendors on the island also showed a widespread distribution, and although there is a slightly higher distribution of dive shops on the leeward (west) side of the island, this is due to reduced wind, drier weather, and a more gently sloping coastline producing better diving conditions.

Table 2: Regional Distribution of Dominican Tourism Accommodation Units, 2008

\begin{tabular}{|l|c|c|c|c|}
\hline \multicolumn{1}{|c|}{ Region } & $\begin{array}{c}\text { No. of } \\
\text { facilities }\end{array}$ & $\begin{array}{c}\text { Percentage of total } \\
\text { facilities }\end{array}$ & $\begin{array}{c}\text { No. of } \\
\text { rooms }\end{array}$ & $\begin{array}{c}\text { Percentage of } \\
\text { rooms }\end{array}$ \\
\hline North & 38 & 27 & 151 & 18 \\
\hline South & 21 & 15 & 111 & 13 \\
\hline West, urban, semi-urban & 42 & 30 & 381 & 44 \\
\hline East & 18 & 13 & 119 & 14 \\
\hline Interior & 21 & 15 & 96 & 11 \\
\hline TOTAL & 140 & 100 & 858 & 100 \\
\hline
\end{tabular}

Source: Visit Dominica (2003 - 2009). ${ }^{4}$

In 2007, hotels accounted for just $29 \%$ of the total number of travel accommodations on the island (Euromonitor International, 2008). This corresponds with the Government's focus on ecotourism, which can come with a preference by visitors for guesthouses and lodges. Weaver (1991) suggests that the potentially allocentric character of tourists to Dominica could make small-scale accommodations more desirable as these tourists seek a more active and authentic local experience. Local ownership predominates in Dominican tourism. Dominicans own the majority of tourism businesses such as accommodation facilities, dive shops and craft shops. Local ownership of accommodation facilities increased from 62\% in 1991 to $88 \%$ in 2004 (Table 3). Also, no pattern exists of diminished local ownership with increased size of hotel, as can be found on many other islands with conventional tourism (Table 3). Ownership by foreigners without Dominican citizenship tends to be by individuals who have lived in Dominica over ten years or have married Dominicans, and many of these individuals consider Dominica to be their home. Most of these foreigners are not absentee owners, but actually live in and run the facilities

\footnotetext{
${ }^{4}$ Accommodation facilities not used primarily for tourist housing were not included in total, e.g. Portsmouth Beach Hotel (now known as Ross University Housing) with 170 rooms used by Ross University's medical students.
} 
themselves. Therefore, it is safe to assume that repatriation of profits from tourism in these cases will be limited. The diverse regional development of ecotourism projects and facilities on the island has led to widespread opportunities for employment throughout Dominica.

Table 3: Ownership and Scale of Accommodation Facilities in Dominica $(\mathrm{N}=75)$.

\begin{tabular}{|c|c|c|c|c|c|c|}
\hline $\begin{array}{c}\text { Size of facility } \\
\# \text { units }\end{array}$ & $\begin{array}{c}100 \% \\
\text { Dominican }\end{array}$ & $\%$ total & $\begin{array}{c}\text { Foreign/ } \\
\text { Dominican }\end{array}$ & $\begin{array}{c}\text { Foreign with } \\
\text { Dominican } \\
\text { citizenship }\end{array}$ & $\begin{array}{c}100 \% \\
\text { foreign }\end{array}$ & Total \\
\hline$<5$ & 21 & 96 & 0 & 1 & 0 & 22 \\
\hline 5 to 9 & 21 & 91 & 0 & 2 & 0 & 23 \\
\hline 10 to 24 & 18 & 78 & 1 & 3 & 1 & 23 \\
\hline Over 25 & 6 & 86 & 0 & 0 & 1 & 7 \\
\hline TOTAL & 66 & 88 & 1 & 6 & 2 & 75 \\
\hline
\end{tabular}

Source: Surveys with Dominican accommodation facilities

\section{Sectoral Linkages}

The second research statement looked at the linkages formed between tourism and other sectors of the Dominican economy. Results show that tourism in Dominica appears to be complementing and linking to other previously established Dominican industries such as agriculture, fishing, and forestry by creating an added demand for goods and services from these industries. For instance, one facility in the southeast of the island, Jungle Bay resort, obtained $90 \%$ of its building material from local sources. Furthermore, $90 \%$ of food prepared in the kitchen at this resort is obtained from the local community through a group of 30 farmers (including former banana workers) and other vendors (Sam Raphael (owner), personal communication, 2008). Survey output indicated that two-thirds of the produce and materials used in tourism facilities in Dominica are made locally, and more than half of these facilities' budgets are spent on obtaining local products. One reason that the quantity of money spent on local products is only slightly higher than money spent on imported products is because items from abroad, including butter, beef, flour, and salt, tend to be more expensive (Table 4). 
Table 4: Use of Locally made Products in the Dominican Tourism Industry $(\mathrm{N}=144)$

\begin{tabular}{|l|c|}
\hline \multicolumn{1}{|c|}{ Data } & Percent \\
\hline Amount of locally made products used in providing their tourism service & 66.3 \\
\hline Amount of foreign products used in providing their tourism service & 33.7 \\
\hline $\begin{array}{l}\text { Amount of facility budget that goes towards obtaining locally made } \\
\text { products for providing their tourism service }\end{array}$ & 51.4 \\
\hline $\begin{array}{l}\text { Amount of the facility budget that goes towards obtaining foreign } \\
\text { products for providing their tourism service }\end{array}$ & 48.6 \\
\hline
\end{tabular}

Source: Surveys with Dominican accommodation facilities, restaurants, craft sellers, and dive shops.

\section{Environmental and Cultural Impacts}

The final research statement considers ecotourism's impact on both the environment of Dominica and on local indigenous culture. The government has created land and marine parks to protect the rainforest and reefs of Dominica. Through the establishment of national parks, such as the Morne Trois Pitons National Park in 1975, the Morne Diablotin National Park in 2000, and the Soufriere/Scott's Head Marine Research in 2001, over 20\% of the island has been allocated to national parks and protected areas (Patterson \& Rodriguez, 2003). Additionally, such legislation as the Forestry and Wildlife Act, the Fisheries Act, and Beach Control Act, has been instituted to protect the island's natural environment. People involved in the Dominican tourism industry overwhelming see nature as both the main attraction for visitors and the resource base for their own livelihoods (Table 5). Tourism businesses also consider the maintenance of the natural environment as a high priority. This view has led to claims of conservation initiatives by $85 \%$ of the individuals in the ecotourism industry surveyed (Table 5).

Table 5: Attitudes of People in Tourism towards Conservation of Local Environment $(\mathrm{N}=264)$

\begin{tabular}{|l|c|}
\hline \multicolumn{1}{|c|}{ Attitude } & Percent \\
\hline Feel that nature is the major reason why visitors come to Dominica & 100 \\
\hline Rely on the surrounding environment for their living & 93.6 \\
\hline $\begin{array}{l}\text { Contribute themselves to conserving or improving their surrounding } \\
\text { environment }\end{array}$ & 85 \\
\hline $\begin{array}{l}\text { Have done more towards conserving or improving their surrounding } \\
\text { environment since being involved in tourism }\end{array}$ & 77 \\
\hline $\begin{array}{l}\text { Feel that more could be done by the Government to conserve } \\
\text { Dominica's natural environment for tourism }\end{array}$ & 85.6 \\
\hline $\begin{array}{l}\text { Feel that more could be done by individuals toward conserving } \\
\text { Dominica's natural environment for tourism }\end{array}$ & 47 \\
\hline
\end{tabular}

Sources: Surveys with Dominican accommodation facilities, restaurants, craft sellers, dive shops, tour companies, tour guides, taxi operators, farmers, fishermen and hucksters. 
While only a minority of the respondents mentioned local awareness and conservation actions as a benefit of ecotourism, people involved in the Dominican tourism industry see nature as both the attraction for visitors and the resource base for their livelihoods. Tourism business people appear to fully understand their reliance on the environment.

Craft makers depend on the environment for materials; farmers for a good agriculture base; and tour guides, dive shops, restaurants, and hotels for sites of interest for visitors. Tourism businesses see maintenance of the environment as a high priority. This view has led to many personal conservation actions by hotel and restaurant owners, tour guides, dive shops, and craft people. Many individuals in the tourism business have incorporated or increased their conservation practices since being involved in Dominican tourism. Measures taken by these individuals include: community and individual beach and river clean-ups, placing boulders to protect against erosion, growing and using organic produce, using Green Globe recommended cleaning products (such as vinegar to clean furniture), educating locals and tourists on conservation, preventing tourists from taking coral, building good sewage systems due to proximity to the sea, using solar heating systems for energy, and composting. For $77 \%$ of respondents, these individual actions toward environmental conservation came as a result of being involved in Dominican tourism. While government policies over time have stated the importance of nature as the tourism focus in Dominica, government actions have at times been contrary to this policy. Some authors have noted the Dominican government's ambivalence over promoting nature-based tourism versus mass tourism, and actions such as advocating attracting foreign investors, including large hotel chains, solidify this concern (Klak, 2007; Weaver, 2004). Both Weaver (2004) and Klak (2007) suggest that this wavering stems from the actions of a fiscally desperate government seeking economic development by any means possible. In Dominica, this conflict has frustrated many individuals and communities involved in tourism, and explains why so many respondents expressed the feeling that the government could do more to conserve the natural environment for tourism (Table 5).

Dominica is home to the Caribs (or Kalinago), the last remaining community of Indigenous people in the region. The Caribs, who provide a unique cultural attraction in Dominica, are located in the Carib Territory on about 3,700 acres of land on the north east coast of Dominica. Caribs were particularly hard hit with the decline in the banana industry since many Caribs were cultivators or banana plantation labourers. In 1993, the Carib Community formulated a management plan with government assistance to promote ecotourism in their Territory (HaySmith \& Harvey, 1995). As a result, some Carib handicraft workers (Figure 6) are reporting income sales of $\$ 3,820$ per year (Slinger, 2000). This amount was $\$ 1,000$ more than the per capita gross national product of Dominica at that time (World Bank, 2000). Other economic opportunities have been created in the Carib Territory as a result of ecotourism, including employment and income earnings as tour guides, guest house owners, and local dance and cultural groups who perform for tourists. Nature sites within the Territory include hiking and biking trails, rivers, waterfalls and scenic ridges. An interesting hiking site is a lava formation called L'Escalier Tete-Chien (stairway of the snake) that emerges from the sea into the mountains. It is said that this stairway enabled the Caribs to visit the mystical snake to 
obtain special powers. With an increasing number of visitors who have an interest in botany and wildlife, Carib tour guides are expected to have knowledge of the flora and fauna in the Territory, and of Dominica in general.

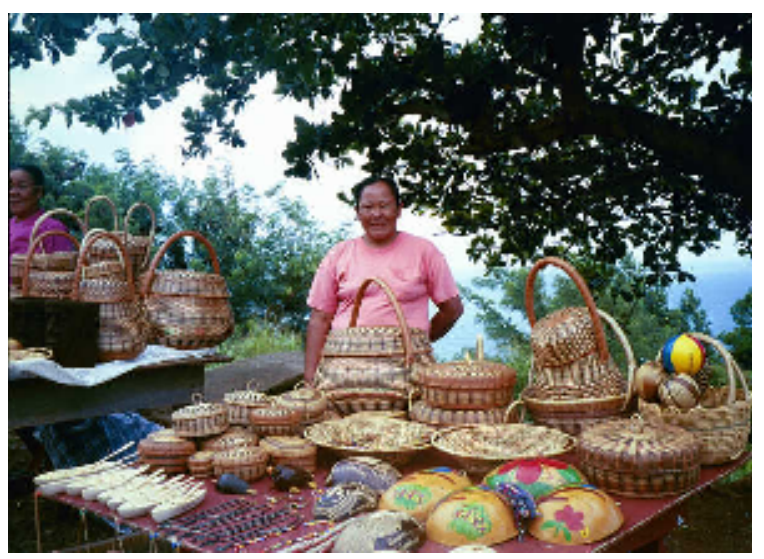

Figure 6: A Carib Woman with her Craft Items for Sale in the Carib Territory (Photo: taken by author).

In terms of cultural preservation, recent efforts have occurred to document the dying Carib language and other cultural information for the revival of crafts, medicines, and traditional music. The report of an examination by Boxill and Severin (2004) concluded that the social impacts of ecotourism on the Caribs are largely positive. A Carib Cultural Village was created as a visitor centre. It was, however, largely rejected by most Caribs who felt that outsiders had too much influence in its running and only benefitted a few particular Carib families (Sam Raphael, personal communication, 2008). Recent plans involving the Dominican government, an International Resort Company (Distinguished International), and the Carib Council, are to modify the Carib Cultural Village in order to develop an EcoLodge Resort and Conference Centre in 2009. The multi-phased projects will feature 100 villas, cottages, and tree-house suites, a 3000 square foot conference centre, dining facilities, spa services, and river-fed natural pools throughout the site. The resort design will incorporate solar heating and indigenous building materials (Hotel News Resource, 2008). The resort could potentially increase tourism earning opportunities in the Territory, one of the poorest communities on Dominica. However, like the original Carib Cultural Village, if it is perceived as being too influenced by outsiders or only for the benefit of a few particular Carib families, then it will face many challenges and be limited in its success.

\section{Research Analysis}

Interestingly, the model of ecotourism found in Dominica shows significant local benefit through ownership, management and general employment opportunities, as well as a potentially higher multiplier effect due to greater linkages between tourism and other sectors of the economy. So far, government policy in Dominica has been beneficial to small-scale locally owned facilities, and with the ecotourism's focus on natural features in rural locations, this type of development has occurred throughout the island. 
This research suggests that certain factors have allowed Dominica to evolve into an ecotourism destination with high levels of local ownership and employment, significant backward linkages, and important regional development. Limited level land has made the construction of a major international airport prohibitively expensive. The runway length at Dominica's Melville Hall Airport in the northeast, 1585 meters, and Canefield Airport in the south, 792 meters, allow only small aircraft to land and neither presently has the facilities for night landings (Wilkinson, 1993, eSTANDARDSFORUM, 2009). Travel to Dominica generally requires a stop-over in such places as Puerto Rico or Jamaica, before arriving on the island. Dominica's physical features, its small size, its island geography, and the lack of an international airport may have acted as blessings in disguise, since they have been discouraging factors for both a high level of foreign visitation and foreign investment into larger tourism facilities. As a result, the facilities that have opened on the island are mostly locally owned, and many are small due to the limited financial resources available to most Dominicans. These are the type of facilities that the government's ecotourism policy has promoted. Because the focus has been on smaller scale establishments, many Dominicans may have felt capable of entering this industry since they would not have to compete with large, well-financed facilities.

The research also suggests that the small-scale, local nature of ecotourism on Dominica has contributed to a greater number of linkages between tourism and other sectors on the island. Larger facilities tend to demand economies of scale that are not available on Dominica and therefore encourage the importation of goods to supply the industry. With the exception of specific products that are not available on the island, the smaller tourism facilities on Dominica can, at present, be supplied by the local primary sector. This research showed high domestic ownership of facilities and a great desire to use locally made goods.

Similar to other Latin American and African countries, government policies in Dominica, have tried to incorporate elements of environmental conservation into tourism planning. In other ecotourism destinations, this has sometimes meant that local populations have lost access to natural resources without obtaining alternative opportunities for their livelihood, particularly where foreigners dominate the ecotourism industry and its benefits. In some cases, this has caused locals to disregard environmental protection measures put in place by their government. In Dominica, individual conservation efforts of people involved in the ecotourism industry have been high due to a reliance on ecotourism and the environment.

Finally, ecotourism seems to be benefiting the local indigenous community through greater recognition, revival, and maintenance of their culture, while providing them with a livelihood that is symbiotic with traditional activities.

\section{Concerns}

While this research has shown some definite benefits from ecotourism in Dominica, the situation is not perfect. Over time, several issues have caused concern over the direction of 
official national tourism planning on the island. Along with the already mentioned development of the cruise ship industry, other actions taken by the Dominica Government have led conservationists and Dominicans in the tourism industry to question their development motives. Controversial actions/decisions have included: (1) the lack of impact assessment at the additional tourist sites that are receiving increasing numbers of tourists (Watty, 2008); (2) the creation of hydroelectric power developments at Trafalgar Falls, Titou Gorge, and Freshwater Lake that have increased noise pollution in these tourist areas and diminished water flow to Trafalgar Falls, a key tourist attraction (Evans \& Williams, 1997; Gayle, 1997); (3) consideration of a cable car system to take large numbers of tourists to the Morne Trois Pitons National Park. This was stopped in part due to public outcry and to the threat by UNESCO to strip the park of its designation as a World Heritage Site (UNESCO, 1998), (4) the way the Government voted at the International Whaling Commission conference in 2002, siding with Japan against a moratorium on whale hunting. Considering that the Dominican tourism industry also relies on whale watching to attract ecotourists, this vote seems contrary to action that would sustain this activity in Dominica (Black, 2005) ${ }^{5}$; (5) the plans of a previous Government to build an international airport that would involved displacing farming communities, destroying mountains and cutting down forest (Fontaine, 2003; Watty 2008) ${ }^{6}$; and (6) the push for a large hotel with foreign backing in the past. The 250 room, 400 time-share unit hotel was to be part of a controversial new 'economic citizenship policy', a government-initiated program whereby foreigners, particularly business people from the Pacific Rim, were sold a Dominican passport in exchange for cash (US\$50,000) or for investing in certain (including tourism based) projects. Due to various reasons, this project was not completed (Nestmann, 2007).

Overall, the Dominican Government has put in place many policies that have encouraged the development of ecotourism on the island. While it is Government policy to encourage small-scale businesses and local participation, local funding and expertise is limited (Wilkinson, 2004). It remains to be seen if the Government's commitment to ecotourism as a main thrust for island development continues in the face of the constant desire for economic growth and pressure from stakeholders interested in the whaling, mineral, and forestry resources of the island. Furthermore, an unemployment rate of $23 \%$ and a net outward migration rate of $5.45 / 1000^{7}$ population create a political and economic environment that pressures the government to grow faster in order to provide opportunities for young Dominicans who will otherwise seek them elsewhere (CIA World Factbook, 2009).

\footnotetext{
${ }^{5}$ It should however be noted that the current Dominican Government did not vote with Japan in favour of commercial whaling at the most recent meeting of the IWC (Eco, 2008; Carter, 2008).

${ }^{6}$ The current Dominican Government has obtained financing from the European Union and Venezuela to pay for the runway extension and upgrading of the existing Melville Hall Airport due to be completed in 2009 (Douglas, 2008).

${ }^{7}$ The emigration rate of Dominica has fallen from 22.39 per 1,000 in 2000, to 5.45 in 2008 (CIA World Factbook, 2000, 2009).
} 


\section{Conclusion}

This study of Dominica shows that ecotourism can have the desired effects of promoting diverse regional development and increasing linkages with other economic sectors while encouraging more sustainable practices regarding the environment and positively impacting the local indigenous culture. The factors that helped achieve these favourable results are a combination of the natural limitations of this small island state along with a government focus on ecotourism development and the development of small scale locally owned facilities. The type of ecotourism model that has developed in Dominica may have transfer potential to similar, small island jurisdictions that are considering developing their tourism industries based on natural resources with the hope of stimulating significant linkages, maintaining local ownership, and facilitating more dispersed regional development.

The development of sun, sea, and sand tourism in the Caribbean has meant that many islands have been slow to promote their other environmental assets. Traditional tourism has typically been dominated by foreign ownership and expatriation of profits. For instance, over half the hotels in both Barbados and Jamaica were in foreign hands (Potter \& Lloyd-Evans, 1997); while in Antigua, 35 out of the 37 major hotels were foreignowned (Pattullo, 1996). Potter \& Lloyd-Evans (1997) have noted that up to $70 \%$ of all tourist expenditure in the Caribbean leaves the islands and ends up in the hotel owners' foreign bank accounts. In contrast, the high percentage of local participation in the industry and the demand for local products suggests that the leakage factor of Dominican tourism is significantly less than the $70 \%$ recorded on other small islands by Milne (1990) and Potter and Lloyd-Evans (1997).

On many islands with traditional tourism, there also exists a spatial effect characterized by pockets of wealth surrounded by the general poverty of much of the local people. In Jamaica, $88 \%$ of the hotel rooms are found in only four locations along the North Coast (Price Waterhouse Coopers, 2004). These pockets of wealth attract locals in search of employment and a perceived chance of a better life; however, tourism employment opportunities for locals in Caribbean islands and other parts of the developing world have been criticized as being low-paying and servile in nature (Cukier, 1998). Pattullo (1996) gives the example of St. Lucia, where there was an estimated 90/10 split between expatriates and locals in senior management positions in the hospitality industry. In contrast, research for this article suggests that ecotourism on Dominica is creating opportunities for a high degree of local participation at all levels of the society in both urban and rural areas of the country.

The urgent need for economic diversification, dispersed regional development, and protection of local environments on other Caribbean islands has led to the search for development alternatives. The physical beauty and diverse flora and fauna of several Caribbean countries such as Grenada, St, Lucia, St. Vincent, Jamaica, and other small island states, offer opportunities for the development of ecotourism. The development of ecotourism in Dominica has significant relevance by providing a potential model for these other islands to follow. 


\section{Acknowledgements}

The author thanks the people of Dominica who assisted with the collection of data, interviews, logistics, and other information. The author also thanks Brian Friedman and anonymous reviewers for their feedback and editorial comments.

\section{References}

Archer, E. (1998) 'Tourism in Barbados' in D. Barker, C. Newby, \& M. Morrissey (eds.) $A$ Reader in Caribbean Geography, Kingston, Jamaica, Ian Randle Publishers, pp. 172-178.

Asiedu, A.B. (1997) 'Prospects for an Emerging Tourism Industry in Ghana', Research Review (new series), Vol. 13, Nos. 1 \& 2, pp. 11-26.

Ayala, H. (1996) 'Resort Ecotourism: a paradigm for the $21^{\text {st }}$ century', Cornell Hotel and Restaurant Administration Quarterly, Vol. 37, No. 5, pp. 46-53.

Black, R. (2005) 'Caribbean Call to Resume Whaling', BBC News, June 22, http://news.bbc.co.uk/2/hi/science/nature/4117888.stm

Blommestein, E. (1995) 'Sustainable Tourism in the Caribbean: An Enigma?' in M. Griffith \& B. Persaud (eds.) Economic Policy and the Environment: The Caribbean Experience. University of the West Indies, Mona, Jamaica, Centre for Environment and Development, pp. 191-220.

Bonnerjea, L. \& Weir, A. (1996) Commonwealth of Dominica Poverty Assessment: Report prepared for the Government of the Commonwealth of Dominica, Roseau, Dominica. Bridgetown, Barbados, British Development Division in the Caribbean.

Boxill, I. \& Severin, F. (2004) 'An Exploratory Study of Tourism Development and Its Impact on the Caribs of Dominica', International Journal of Hospitality \& Tourism Administration, Vol. 5, No. 1, pp. 1-27.

Britton, S.G. (1982) 'The Political Economy of Tourism in the Third World', Annals of Tourism Research, Vol. 9, No. 3, pp. 331-358.

Brohman, J. (1996) 'New Directions in Tourism for Third World Development', Annals of Tourism Research, Vol. 23, No. 1, pp. 48-70.

Caribbean Conservation Association (CCA) (1991) Dominica: Country Environmental Profile. St. Michael, Barbados, CCA and Island Resources Foundation.

Caribbean Net News (2009) 'Dominicans urged to continue increasing Country's Market Share', January 7 , 
www.caribbeannetnews.com/dominica/dominica.php?news_id $=13382 \&$ start $=40 \&$ category $\underline{\mathrm{id}=31}$

Caribbean Tourism Organization (CTO) (2004) 'Dominica', Division of Tourism, National Development Corporation, Department of Statistics, Dominica, www.onecaribbean.org/content/files/2004dominica.pdf.

Caribbean Tourism Organization (CTO) (2007) 'Dominica', Division of Tourism, National Development Corporation, Department of Statistics, Dominica, www.onecaribbean.org/content/files/Dominica2006.pdf.

Carter, E. (2008) 'Dominica drops Support for Commercial Whaling', TheDominican.net, June 10, www.thedominican.net/2008/06/dominica-drops-support-for-commercial.html.

Central Statistical Office (CSO) (1999) Annual Travel Report. Roseau, Dominica, Government Statistical Office.

CHL (1999) 'Ecotourism Development Programme Design and Costing Study. Volume II Stabex Community Development Programme', Dublin, Ireland, CHL Consulting Group.

CHL (2006) 'Tourism Master Plan 2005 - 2015. Consulting services for the Preparation of a Tourism Master Plan 2005-2015. Commonwealth of Dominica, $2^{\text {nd }}$ Draft Final Report' London, U.K., CHL Consulting Group.

CIA World Factbook (2000) 'Dominica', www.umsl.edu/services/govdocs/wofact2000/geos/do.html.

CIA World Factbook (2009) 'Dominica', www.cia.gov/library/publications/the-worldfactbook/geos/do.html.

Caribbean Tourism Organization (CTO) (1993) Dominica Visitor Survey, ChristChurch, Barbados.

Cukier, J. (1998) 'Tourism Employment and Shifts in the Determination of Social Status in Bali' in G. Ringer (ed.) Destinations: Cultural Landscapes of Tourism, New York, Routledge, pp. 63-79.

Douglas, S. (2008) 'We are in the Home Stretch says Hon. Charles Savarin during Site Visit at Melville Hall Airport', Government of the Commonwealth of Dominica, press release, November 24, www.dominica.gov.dm/cms/index.php?q=node/674.

Duval, D.T. (2004) 'Trends and Circumstances in Caribbean Tourism' in D.T. Duval (ed.) Tourism in the Caribbean: Trends, Development, Prospects, London, Routledge, pp. 1-22.

Eco (2008) 'IWC Vote Buying', Eco International Whaling Commission Annual Meeting, June 2, Eco, Vol. 60, No. 1, www.asoc.org/Portals/0/2008\%20Eco\%20No\%201.pdf. 
Encyclopedia of the Nations (2008) 'Dominica: Agriculture', www.nationsencyclopedia.com/economies/Americas/Dominica-Agriculture.html.

eSTANDARDSFORUM (2009) 'Country Brief: Dominica January 20, 2009', eStandardsForum Financial Standards Foundation, www.estandardsforum.org/secure content/country profiles/cp 63.pdf.

Euromonitor International (2007) 'Travel and Tourism in Dominica', Research and Markets, www.researchandmarkets.com/reports/515169/travel_and tourism_in dominica.

Euromonitor International (2008) 'Travel and Tourism in Dominica', www.euromonitor.com/Travel_And_Tourism in Dominica.

Evans, P.G.H. \& Williams, D. (1997) Development and Management of Nature Sites Integrating Conservation with Ecotourism in Dominica, Project Report No. 4, Brussels, European Community Project No. B7-5040-24. Ecosystems Ltd.

Fontaine, T. (2003) 'No International Airport for Dominica', TheDominican.net, No. 42, May 7, www.thedominican.net/articles/airport.htm.

Gayle, D.J. (1997) 'Ecotourism: Fad or Future?', Hemisphere: A Magazine of the Americas, Vol. 8, No. 1, pp. 20-23.

Halcrow Group Ltd. (2003) 'Caribbean Development Bank Government of the Commonwealth of Dominica Country Poverty Assessment, Final Report Volume 1 of 2: Main Report', London, Halcrow Group Ltd.

HaySmith, L. \& Harvey, J. (1995) Nature Conservation and Ecotourism in Central America. New York, Wildlife Conservation Society.

Honey, M. (1999) Ecotourism and Sustainable Development: Who Owns Paradise? Washington DC, Island Press.

Honey, M. (2008) Ecotourism and Sustainable Development: Who Owns Paradise? $2^{\text {nd }}$ edition, Washington DC, Island Press.

Honychurch, L. (1991) Dominica: Isle of Adventure, Basingstoke, Macmillan.

Hotel News Resource (2008) Government of Dominica Supports Eco-Lodge Project Proposed by Distinguished International Hotels, Residences and Resorts, http://www.hotelonline.com/News/PR2008 3rd/Aug08 DominicaEcoLodge.html.

Hulme, P. (2007) 'Meditation on Yellow: Trade and Indigeneity in the Caribbean' in L. Dale \& H. Gilbert (eds.) Economies of Representation 1790-2000: Colonialism and Commerce, Aldershot, Ashgate, pp. 3-16. 
Hypolite, E., Green, G.C. \& Burley, J. (2002) 'Ecotourism: its potential role in forest resource conservation in the Commonwealth of Dominica, West Indies', International Forestry Review, Vol. 4, No. 4, pp. 298-306.

Johnson, D. (2006) 'Providing Ecotourism Excursions for Cruise Passengers', Journal of Sustainable Tourism, Vol. 14, No. 1, pp. 43-54.

Klak, T. (1998) 'Caribbean Development Policies in a Neoliberal Era: Case Studies' in T. Klak (ed.) Globalization and Neoliberalism: The Caribbean Context, Oxford, Rowman \& Littlefield Publishers, pp. 111-134.

Klak, T. (2007) 'Sustainable Ecotourism Development in Central America and the Caribbean: Review of Debates and Conceptual Reformulation', Geography Compass, Vol. 1, No. 5, pp. 1037-1057.

Klak, T. \& Flynn, R. (2008) 'Sustainable Development and Ecotourism: General Principles and Eastern Caribbean Case Study' in E. Jackiewicz \& F.J. Bosco (eds.) Placing Latin America, Lanham MA, Rowman and Littlefield, pp. 115-136.

Latin American Bureau (1987) Green Gold: Bananas and Dependency in the Eastern Caribbean, Birmingham, Third World Publications.

McElroy, J.L. (2004) 'Global Perspectives in Caribbean Tourism' in D.T. Duval (ed.) Tourism in the Caribbean: Trends, Development, Prospects, London, Routledge, pp. 3956.

Ministry of Tourism and National Development Corporation (2005) Dominica: Tourism 2010 Policy. Roseau, Dominica.

Milne, S. (1990) 'The Impact of Tourism Development in Small Pacific Island States: An Overview', New Zealand Journal of Geography, Vol. 89, pp.16-21.

Nestmann, M. (2007) 'Whither Dominica', http://nestmannblog.sovereignsociety.com/2007/04/whither_dominic.html.

Patterson, T. \& Rodriguez, L. (2003) 'The Political Ecology of Tourism in the Commonwealth of Dominica' in S. Gössling (ed.) Tourism and Development in Tropical Islands: Political Ecology Perspectives, Cheltenham, Edward Elgar, pp. 60-87.

Pattullo, P. (1996) Last Resorts: The Cost of Tourism in the Caribbean, New York, Cassell.

Place, S.E. (1998) 'How Sustainable is Ecotourism in Costa Rica?' in M.C. Hall \& A.A. Lew (eds.) Sustainable Tourism: A Geographical Perspective, New York, Longman, pp. 107-118. 
Potter, R.B. \& Lloyd-Evans, S. (1997) 'Sun, Fun \& a Rum Deal: Perspectives on Development in the Commonwealth Caribbean', FOCUS, Vol. 44, No. 4, pp. 19-26.

Price Waterhouse Coopers (2004) 'The Jamaican Hotel Industry: 2004', www.pwc.com/cb/images/pdf/jamaicahotel2004.pdf.

Progressive Policy Institute (2004) 'Caribbean Banana Exports are Down', May 12, www.ppionline.org/ppi ci.cfm?knlgAreaID=900003\&contentID=252628.

Shamsub, H., Albrecht, W., \& Dawkins, R. (2006) 'Relationship between Cruise-ship Tourism and Stayover Tourism: A Case Study of the Shift in the Cayman Islands' Tourism Strategy', Tourism Analysis, Vol. 11, pp. 95-104.

Slinger, V. (2000) 'Ecotourism in the Last Indigenous Caribbean Community', Annals of Tourism Research, Vol. 27, No. 2, pp. 520-523.

UNESCO (1998) Convention Concerning the Protection of the World Cultural and Natural Heritage, Bureau of the World Heritage Committee, $22^{\text {nd }}$ Session, Paris, France, http://whc.unesco.org/archive/repbur98a.htm

US Department of State (2009) Background Note: Dominica, Under Secretary for Public Diplomacy and Public Affairs, www.state.gov/r/pa/ei/bgn/2295.htm.

Visit Dominica (2003-2009) 'Visit Dominica', www.visit-dominica.com/form2.cfm.

Watty, W.R.F. (2008) Feature Address W. R. Franklin Watty, Chairman of Diaspora Affairs, Dominica Academy of Arts and Sciences at the Annual Awards Gala Dominica Hotels and Tourism Association, http://da-academy.org/Watty_Address_DHTA.pdf.

Weaver, D.B. (1991) 'Alternative to Mass Tourism in Dominica', Annals of Tourism Research, Vol. 18, No. 2, pp. 414-432.

Weaver, D.B. (1998) Ecotourism in the Less Developed World, New York, CAB International.

Weaver, D.B. (2004) 'Manifestations of Ecotourism in the Caribbean' in D. T. Duval (ed.) Tourism in the Caribbean: Trends, Development, Prospects, New York, Routledge, pp. 172-186.

Westbrook, T., Mendelssohn, G. \& Evans, P.G.H. (1997) Stayover Visitor Survey 19951996. Project Report No. 6: Integrating Conservation with Ecotourism in Dominica, Brussels, European Community Project No. B7-5040-24, Ecosystems Ltd.

Wilkinson, P.F. (1993) Tourism Policy and Planning in the Eastern Caribbean: Anguilla, Barbados, Dominica and St. Lucia - Report on a Research Project, Ontario, Canada, York University, Faculty of Environmental Studies. 
Wilkinson, P.F. (2004) 'Caribbean Tourism Policy and Planning' in D.T. Duval (ed.) Tourism in the Caribbean: Trends, Development, Prospects, New York, Routledge, pp. 8198.

Woods, L.A., Perry, J.M. \& Steagall, J.W. (1998) 'Tourism in Belize' in D. Barker, C. Newby \& M. Morrissey (eds.) A Reader in Caribbean Geography, Kingston, Jamaica, Ian Randle Publishers, pp. 179-190.

World Bank (2000) World Development Indicators 2000, CD-ROM, Washington DC, World Bank.

WTO (2009) 'Regions: The Americas', UNWTO World Tourism Barometer, Vol. 6, No. 1, pp. 21-25, www.unwto.org/facts/eng/pdf/barometer/UNWTO_Barom08_1_en.pdf. 